JASSI_anakku Volume 20 Nomor 2, Desember 2020

\title{
PENYUSUNAN INSTRUMEN TES UNTUK MENGUKUR BAHASA RESEPTIF DAN EKSPRESIF ANAK TUNARUNGU (HEARING IMPAIRMENT)
}

\author{
Dena Tresna Aripiani*, Budi Susetyo, Iding Tarsidi \\ Departemen Pendidikan Khusus, Fakultas Ilmu Pendidikan, Universitan Pendidikan \\ Indonesia, Bandung, Indonesia \\ *denatresna@student.upi.edu
}

\begin{abstract}
A good test measuring tool is one that meets the requirements for the preparation of the test, namely the validity and reliability testing. This study aims to develop a receptive and expressive language instrument for children with hearing impairment. The arrangement of this instrument was adapted from the TOLD-P instrument or a test of language which was modified using Indonesian and made simpler consisting of picture vocabulary, oral vocabulary, and phoneme analysis. The method used in this study used a pre-xxperimental design experimental method with the type of one group posttest. The results of the content validity of this study get a CVR value > 0 that is, 1 , while the stability reliability is 0.941 which means it is classified as very high reliability. The test instrument prepared by the researcher has met the good test requirements. Thus the test instrument can be used even for a limited circle. This is because the test instrument is still in the form of an initial draft and has not been tested for a wide range of people, so the instrument is not standardized and needs to be standardized.
\end{abstract}

Keywords: Hearing Impairment, Instrument Arrangement, Test Of Language Development-Primary Third.

\begin{abstract}
ABSTRAK
Alat ukur tes yang baik adalah yang memenuhi syarat-syarat penyusunan tes yakni adanya pengujian validitas dan reliabilitas. Penelitian ini bertujuan untuk menyusun sebuah instrumen bahasa reseptif dan ekspresif bagi anak tunarungu. Penyusunan instrumen ini diadapatasi dari instrumen TOLD-P atau test of language yang dimodifikasi dengan mengggunakan bahasa Indonesia dan dibuat lebih sederhana yang terdiri dari picture vocabulary (kosakata gambar), oral vocabulary (kosakata lisan), dan analysis fonem (analisis fonem). Metode yang digunakan dalam penelitian ini menggunakan metode eksperimen prexxperimental design dengan jenis one group postes. Hasil dari validitas isi penelitian ini mendapatkan nilai CVR > 0 yakni,1, sedangkan reliabilitas stabilitas sebesar 0,941 yang artinya tergolong reliabilitas sangat tinggi. Instrumen tes yang disusun peneliti telah memenuhi syarat tes yang baik. Dengan demikian instrumen tes sudah dapat digunakan meskipun untuk kalangan terbatas. Hal ini disebabkan instrument tes masih berupa draf awal belum diujicobakan untuk kalangan yang luas, sehingga instrument belum standard dan perlu distandarisasikan.
\end{abstract}

Kata Kunci: Anak Tunarungu, Penyusunan Instrumen, Test of Language 


\section{JASSI_anakku Volume 20 Nomor 2, Desember 2020}

\section{Pendahuluan}

Secara umum anak tunarungu yang mengalami hambatan dalam pendengarannya memiliki perbedaan dengan anak mendengar. Kurangnya pendengaran akan mempengaruhi pada proses komunikasi, pengertian, pembicaraan, membaca dan bahasa reseptif dan ekspresif. Hal ini akan berdampak pada kesulitan dalam menangkap bunyi bahasa dari sekitar lingkungannya, sehingga kosakata yang dimilikinya sangat minim karena bank suara anak tunarungu (hearing impairment) kosong tidak ada suara. Sehingga ketidakberfungsian indera pendengaran dalam mengakses bunyi-bunyi bahasa yang terjadi di lingkungannya anak tunarungu (hearing impairment) mengoptimalkan indera lainnya dari segi visualnya.

Salah satunya pemberian kosakata pada anak tunarungu (hearing impairment) dinilai sangat penting. Pengembangan keterampilan bahasa anak tunarungu (hearing impairment) bisa dilakukan melalui interaksi secara teratur maupun dari alat ukur tes atau disebut instrumen. Namun faktanya tidak semua sekolah memiliki alat tes ukur atau instrumen yang dapat mengukur kemampuan bahasa pada anak tunarungu baik reseptif maupun ekspresif. Salah satunya yang ditemukan oleh peneliti adalah SLBN A Cituereup Cimahi dan PK-PLK Cimahi, sejatinya seorang guru sudah memliki alat ukur tes untuk dapat menilai kemampuan yang dimiliki oleh tiap siswa. Dengan adanya alat ukur tes/ instrumen tersebut dapat mengetahui kemampuan, hambatan dan kebutuhan siswa.

Oleh karena itu tujuan dalam penelitian ini adalah menyusun instrumen tes untuk mengukur bahasa (reseptif dan eskpresif) bagi anak tunarungu kelas satu SDLB sehingga dapat memberikan sumbangan pemikiran pada perkembangan ilmu pendidikan khusus maupun sekolah dalam penyusunan instrumen tes bahasa untuk mengukur bahasa reseptif dan ekspresif anak tunarungu (hearing impairment).

\section{Metode Penelitian}

Metode penelitian merupakan proses yang sangat diperlukan untuk memberikan hasil yang sesuai dengan penelitian yang akan dilakukan. Dalam penelitian ini metode yang digunakan oleh peneliti yakni, menggunakan metode eksperimen pre- 


\section{JASSI_anakku Volume 20 Nomor 2, Desember 2020}

experimental design. dengan jenis one group postest. Metode eksperimen one group postest ini artinya tanpa memberikan pretest sebelum diberikan perlakuan. Perlakuan disini berupa instrument tes bahasa reseptif dan ekspresif yang dibuat dan diuji cobakan kepada peserta tes atau siswa. Sedangkan yang dimasuksud dengan postes adalah hasil pengukuran dari instrument yang dibuat yaitu berupa skor hasil tes.

Berikut ini rumus yang digunakan peneliti sebagai berikut:

\begin{tabular}{|c|}
\hline \\
\hline
\end{tabular}

Keterangan

$\mathrm{X}=$ Instrumen Tes

$\mathrm{O}=$ Postes atau hasil tes

Instrumen penelitian merupakan alat tes ukur yang harus digunakan untuk mengetahui kemampuan anak baik yang nampak maupun yang tidak. Dengan adanya sebuah alat ukur tes maka data yang diperoleh akan lebih akurat dan dapat dijadikan sebuah evaluasi/intervensi. Instrumen dalam penelitian ini peneliti mengadaptasi dan memodifikasi bentuk penyusunan yang telah dibuat oleh Newcomer \& Hammill (1997) dalam bentuk yang telah baku dan peneliti mengadaptasikan bentuk instrumen tersebut dengan bentuk instrumen yang dibuat peneliti sendiri dengan menggunakan bahasa Indonesia agar lebih mudah dipahami dan dibuat lebih sederhana.

Tes ini berbentuk tes lisan dan perbuatan. Menurut Susetyo, B. (2015, hlm.5) "tes lisan merupakan tes yang dalam pelaksanaannya dilakukan secara lisan". Sedangkan tes perbuatan merupakan "tes yang menuntut peserta untuk melakukan sesuatu sesuai dengan butir-butir tes yang ada". (Susetyo, B. 2015, hlm. 6). Berikut ini bagan penyusunan tes sebagai berikut: 




Gambar 1. Prosedur

Sedangkan analisis data yang digunakan dalam penelitian ini menggunakan validitas isi. Menurut Susetyo, B. (2015, hlm. 113) validitas isi adalah validitas yang akan mengecek kecocokan di antara butir-butir tes yang dibuat dengan indikator, materi atau tujuan pembelajaran yang telah ditetapkan. Untuk perhitungan validitas isi ini peneliti menggunakan rumus perhitungan rasio validitas isi dari $\mathrm{C} \mathrm{H}$ Lawshe dengan format dikotomi, dengan cocok $=1$ dan tidak cocok $=0$. dengan rumus sebagai berikut:

$$
\text { CVR }=\frac{2 M p}{M}-1
$$

Analisis data lainnya adalah menggunakan pengujian reliabilitas. Dalam penelitian ini reliabilitas yang digunakan adalah reliabilitas stabilitas. Menurut Susetyo, B. (2015, hlm. 143) pengujian realibilitas menggunakan satu perangkat ukur dan dikenal juga sebagai uji ulang (test retest) dengan menggunakan rumus sebagai 


\section{JASSI_anakku volume 20 Nomor 2, Desember 2020}

berikut: $\rho_{A 1 A 2}=\frac{N \sum A_{1} A_{2}-\left(\sum A_{1}\right)\left(\sum A_{2}\right)}{\sqrt{\left[N \sum A_{2}^{1}-\left(\sum A_{1}\right)^{2}\right]\left[N \sum A_{2}^{2}-\left(\sum A_{2}\right)^{2}\right]}}$

Oleh karena itu pada pelaksanaan uji reliabilitas ini para ahli berpendapat untuk memberikan rentang waktu selama tiga minggu dari pelaksanaan tes pertama dengan yang kedua. Uji coba tes ini dilakukan di dua sekolah yakni, SLBN A Citeureup Cimahi dan PK-PLK Cimahi dengan masing-masing sekolah responden berjumlah dua orang pada kelas satu SDLB.

\section{Hasil dan Pembahasan}

Pada perhitungan validitas tahap I diperoleh kesimpulan yakni diketahui bahwa butir istrumen mendapat nilai CVR $>0$ dan beberapa juga memperoleh nilai CVR $<0$ oleh karena itu dapat disimpulkan bahwa instrumen yang dibuat oleh peneliti pada tahap satu ini belum semua ahli menilai instrumen tes ini sesuai sehingga instrumen harus direvisi kembali . Kemudian pada validitas tahap II ini menunjukkan hasil bahwa butir instrumen yang sudah direvisi peneliti mendapatkan nilai CVR $>0$ yakni,1. Oleh karena itu para ahli menyatakan butir instrumen tes layak diuji cobakan untuk anak tunarungu kelas satu sekolah dasar.

Sedangkan berdasarkan perhitungan reliabitas stabilitas reliabilitas sebesar 0,941 dan dapat disimpulkan perangkat tes tergolong sangat tinggi. Tes pertama dilakukan pada tanggal 12 dan 13 Oktober dan tes kedua dilaksanakan pada tanggal 31 Oktober 2020. Tes pertama BPMD mendapatkan skor 60 (instructional level), FA 71 (instructional level), MAH 42,9 dan MRF 42,9 (frustation level). Kemudian tes kedua BPMD memperoleh skor 85,7 (independent level), FA 85,7(indenpendent level), MAH 45,7, dan MRF 42,9 (frustation level).

Hasil penelitian yang berupa penyusunan instrument tes telah memenuhi persyaratan dari segi persyaratan yang baik yaitu validitas dan reliabilitas, dan dari segi konstruksi tes yang dimulai dari penetapan dimensi yang diukur sampai penyusunan butir tes. Instrumen tes yang disusun telah mengikuti prosedur penyusunan tes sesuai dengan langkah-langkah secara teori yang dikemukakan oleh beberapa ahli dan penyusunan tes dengan teori ujian klasik. Dengan demikian instrumen tes sudah dapat digunakan meskipun untuk kalangan terbatas. Hal ini 


\section{JASSI_anakku volume 20 Nomor 2, Desember 2020}

disebabkan instrument tes masih berupa draf standard dan perlu distandarisasikan

\section{Kesimpulan}

Berdasarkan hasil pengolahan data tentang penyusunan tes instrumen maka dapat ditarik kesimpulan yaitu penyusunan instrument dapat digunakan untuk mengukur bahasa reseptif dan eskpresif anak tunarungu. Meski instrumen tes yang disusun ini masih dilakukan uji dalam jumlah terbatas dan belum diujicobakan dalam kalangan yang luas oleh karena itu hasilnya belum dapat digunakan secara luas karena masih berupa draf belum standar karena diuji cobakan kepada beberapa orang saja. Untuk penyusunan instrumen bahasa yang dibuat oleh peneliti sudah sesuai dengan syarat tes yang baik dan tepat untuk mengukur bahasa reseptif dan ekspresif anak tunarungu karena peneliti sendiri telah melakukan pengujian validitas dan reliabilitas instrumen dikonstruksi sesuai dengan teori ujian klasik.. Oleh karena itu penyusunan instrumen tes memenuhi syarat instrumen yang baik dan hasilnya menujukkan stabilitas.

\section{Referensi}

Delphie, B. (2009). Pembelajaran Anak Berkebutuhan Khusus Dalam Setting Pendidikan Inklusi. Yogyakarta: Intan Sejati.

Fawzi, M.H. (2005). Bahasa Kasih Memahami Masalah Ketunarunguan. Bandung: Angkasa.

Indriati, E. (2011). Kesulitan Bicara dan Berbahasa Pada Anak. Jakarta: Prenadamedia Group.

Otto, B. (2015). Perkembangan Bahasa Pada Anak Usia Dini. Jakarta: Prenamedia.

Sugiyono. (2015). Metode Penelitian Pendidikan Pendekatan Kuantitatif, Kualitatif, Dan R\&D. Bandung: Alfabeta.

Susetyo, B. (2015). Prosedur Penyusunan dan Analisis Tes Untuk Penilaian Hasil Belajar Bidang Kognitif. Bandung: Refika Aditama.

Tarigan, H. G. (2015). Membaca Sebagai Suatu Keterampilan Berbahasa. Bandung: Angkasa.

Widoyoko, E. P. (2012). Teknik Penyusunan Instrumen Penelitian. Yogyakarta: Pustaka Pelajar. 